\title{
The TRIPS agreement implementation in Mexico. Implications for social responsibility and development
}

\section{Santiago González-Gomez}

School of Economics and Business Management Sciences,

Universidad Panamericana,

México

sgon₹ale:@up.edu.mx

\section{Arturo García-Santillán}

UCC Business School, Universidad Cristóbal Colón,

México

arturogarciasantillan@yahoo.com.mx

Abstract. The relation between intellectual property vs international commerce can be either positive, or negative, favoring certain countries with better technological infrastructure or increasing their international commerce, but it might also represent a barrier to commerce in case of abuse with its implementation. It could also be an impediment for social responsibility, remarkably in case of developing nations. This research focuses on intellectual property rights in Mexico, its effects on international competitiveness, and analyzes the influence of the TRIPS ${ }^{1}$ Agreement on Mexico's technological

Received: August, 2018 1st Revision: December, 2018 Accepted: May, 2019

DOI:

Keywords: Intellectual property, competitiveness, international commerce, social responsibility, modernization, México.

JEL Classification: O34, M14

\section{INTRODUCTION}

In order to stay competitive companies are supposed to renew their technologies applied to basic processes delivering their products and/or services to clients.

Four basic factors reflect country's competitiveness: installed technological capacity; the level of innovation; knowledge and professional development of their inhabitants; and governments' deregulation allowing the creation of new companies.

\footnotetext{
${ }^{1}$ Trade-Related Aspects of Intellectual Property Rights, TRIPS
} 
Concerning technological development and nations' capacity to use technology in everyday performance, the World Economic Forum, WEF, carried out a study and calculated the Technological Index in 2016 (Technological Readiness). Mexico was then ranked 73rd out of 138 studied countries with 4.0 points and also 51st in global competitiveness, with 4.41 points (WEF, 2016-2017). Switzerland tops the list of technological readiness leaders having 6.4 points, as well as the Competitiveness Global Index, with 5.8 points. However, Mexico is one of Latin America's most efficient technology importers, due to the operative influence of multinational companies that implement systems operated by domestic workers. Technology transference is already embedded in Mexico's economic life, although in terms of generation, research and technological development, it still needs to be propelled closer to international standards.

Production and commerce of technology-intensive goods have expanded during the last two decades, particularly in the new technologies sectors. In the1980s, organizations linked to the industry produced diverse studies and documents quantifying the losses due to the commerce of forged merchandises as a result of inefficient or ineffective protection of intellectual property.

Protection and observance of these rights vary considerably in different countries and as intellectual property acquires more importance in commerce, these differences turn into a source of tensions in international economic relations.

The way to achieving more order and predictability and at the same time allowing to solve more systematically these differences would be setting new commercial, internationally agreed, norms in the sphere of intellectual property rights. The Uruguay Round achieved it. The World Trade Organization, WTO, Agreement on the TRIPS, presents an attempt to reduce the differences in the ways of protecting those rights internationally according to common international norms. This agreement presents some minimum protection levels that each government must consent to the intellectual property of the rest of the WTO members.

Here we would like to address the issue of intellectual property vs. Mexico's international commerce, taking into account that intellectual creation object of commerce is also affected by international agreements regulating trade.

\section{LITERATURE REVIEW}

\subsection{Commerce protection or commerce distortion?}

In 1979, in Stockholm, Sweden, the developing countries set out the review of the Paris Agreement on Intellectual and Industrial Property and remarked among other argumentations, the effect of the patents systems on commerce and imports. Nevertheless, the effects that intellectual property has on international commerce became relevant when this topic was included in $1984 .^{2}$

The importance of intellectual property at international commerce varies according to technology and specifications of the countries and the corresponding sectors. Currently, intellectual property has a strong impact on the exports of developed nations like the Group of 7 (Canada, France, Germany, Italy, Japan, United Kingdom and the United States) and the "Asian Tigers" (Hong Kong, Singapore, South Korea and Taiwan). However, regarding less developed countries, the relevance of intellectual property in their exports flow is significantly lesser due to their low degree of technological specialization. The first ones become, therefore, exporters of products with a high value added due to the use of technological innovation and the second ones become consumers. This dichotomy has led so far every political, economic or legal analysis about this subject.

\footnotetext{
${ }^{2}$ From section 301 of the Law of Commerce of the United States and the initiative of negotiating at the Uruguay Round of the GATT, on intellectual property subjects.
} 
According to the article "The TRIPS Agreement and the legitimacy crisis of the WTO", (Martín Khor, 2003):

"When the Uruguay Round of negotiations on multilateral commerce was launched, some developed nations did not accept including in the agenda the subject on intellectual property rights. However, the United States put pressure and those nations, in the end, had to give up. Consequently, the Trade-Related Aspects of Intellectual Property Rights, (TRIPS), became part of the family of agreements of the World Trade Organization (WTO)". An important data is that the pressure made by the more developed nations (including the North's industries that pressured for the TRIPS) were able to set rules that, according to some experts, constitute an imminent danger for the development perspectives of the poor nations".

Bondía (1998), says that intellectual property relates to the creations of the mind: inventions, literary and artistic works, symbols, names, images, drawings and models used in commerce.

The intellectual property economic theory is clear. Unlike the general case, where market price sets an equilibrium between offer and demand without the need for rents, these are justified at the "knowledge market" as the necessary incentive for research and invention. The market price itself would not be enough for this aim. There is an excess of rents when its higher value does not encourage a bigger effort on research and invention, however, it is certainly a disincentive for technology transference. Any developed nation shows an interest in not surpassing that upper limit. All of them happily increase the protection levels and develop ways of "harder" protection norms disdaining the consequences.

Adam Smith (1776), defends the advantages of international commerce in order to increase the nations' wealth and the standard of living. This theory considers that some nations count with a different amount of natural resources. Since each nation is a specialist in the manufacturing of one or several products, there is also a certain number of hours needed in order to obtain each product unit.

Each country has a certain degree of technological development and counts with different knowledge. The differences in knowledge and technology between nations, give place to differences in the production processes and products. Therefore, different products are manufactured which later are exchanged at the international market. In that sense, "the relation between international commerce and intellectual property has been visualized from two complementary perspectives: The lack of protection as an obstacle to commerce and the abuse of rights that lead to wrongful restrictions from the competition". (Smith, 1995, p.16).

In the first case, the Uruguay Round (Uruguay Round Agreements Act/Title V, Intellectual Property, 1994), accepted that "the intellectual effort integrated to merchandises constitutes a part of its own value, the same way as if it was a material supply. The insufficiency or inefficiency of the protection of the intangible elements of a merchandise value has the same harmful effects on the international commerce as the lack of property rights of physical merchandises". This proposal makes emphasis on the distortions created at the international commerce by unsatisfactory protection levels and observance of intellectual property rights. The second perspective considers that the abuse of exclusive rights given by the intellectual property titles might become barriers to trade. The consequence: a restriction of international competition, giving place to adverse effects on access to technology, price levels of protected products or in the technological advance.

According to the definition adopted after the Uruguay Round (1994), in the TRIPS agreement, most of the substantive aspects of those rights might affect commerce. The agreement specifies minimum standards on the subject, with the objective of setting an equilibrium between the producer's interests and the users of technology, as well as assuring that the use of those rights would not lead to noncompetitive practices. Each nation is able to apply the new rules, according to its own legal system.

Most of the legislative action on intellectual property is present at the frame of integration processes like the Central America Common Market, CACM, trademarks; the Andean Community, CAN, the G3, 
and NAFTA. The negotiation process that began at the Summit of the Americas has also included the intellectual property subject.

One of the premises of initiatives leaning to link intellectual property regulation has been that the volume of commerce of goods protected by intellectual property rights "is increasingly significant as more countries produce and consume products resultant from creative activity or innovation or are well known for its quality" (GATT, 1987a, p.1).

Beyond the insufficiency of available data, production and commerce of intensive goods in technology have been expanding during the last two decades, particularly in the new technologies sectors.

"The evolution of the intellectual property system at international level has been propelled, mainly, by the most developed nations. The explanation of the evolution of intellectual property in Latin America, then, is related to the evolution propelled by the developed countries". (Pérez Miranda, 1994, p.78)

The competitiveness level brought by the strengthening of intellectual property has led these nations to put pressure on the Latin American countries through agreements like the TRIPS.

In the decade of the sixties Latin American countries, like Mexico began a process in order to modify their laws on intellectual property subjects. The modifications made to the intellectual property legislative system were the reduction of the number of patentable products, lasting of the exclusive rights monopoly and impulse of the national use of inventions. (Roffe, 1987). Since then, these countries have reformulated their intellectual property systems according to the technological advance needs. During the last two decades, it has evolved and nowadays some countries have some of the most advanced protection systems.

According to Roffe (1985), since the end of the past century, several Inter- American conventions have taken place on the regulation of diverse aspects of intellectual property and copyrights. Joining these conventions has been odd. Nevertheless, they constitute a very important background to pay attention to every effort with a hemispherical character.

"In relation to copyright, several conventions have been subscribed: México (1902), Río de Janeiro (1906), Buenos Aires (1910), The Caracas Agreement (1911) Havana (1928) and Washington (1946), and the Montevideo Agreement on the literary and artistic property (1889)" (Pérez Miranda, 1994, p.68)

Intellectual property is a cluster of rights that corresponds to certain persons on the works that are a creation of their intelligence.

"Intellectual property of a literary, artistic or scientific work corresponds to its author by the simple fact of creating it. An author is a natural person that creates an artistic, scientific or literary work. It will be a presumed author, unless the proof on the contrary, the one who appears like that at the work, through his or her name, signature or sign that may identify this person. When somebody disseminates a work anonymously or under a pseudonym or sign, the exercise of intellectual property rights shall correspond to the natural or legal person that brings it to light with the consent of the author, as long as this one does not reveal his or her identity. The dissemination of a work is every expression of this that, with the author's consent, makes it accessible by the first time to the public in any form" (Jalife \& Mauricio, 1994, p.120).

Objects of intellectual property are the original literary, artistic or scientific creations expressed by any medium or support, tangible or intangible, currently known or invented in the future.

According to the article "The TRIPS Agreement and the legitimacy crisis of the WTO", (Martín Khor, 2003): 
"When the Uruguay Round of negotiations on multilateral commerce was launched, some developed nations did not accept including in the agenda the subject on intellectual property rights. However, the United States put pressure and those nations, in the end, had to give up. Consequently, the Trade-Related Aspects of Intellectual Property Rights, (TRIPS), became part of the family of agreements of the World Trade Organization (WTO)". An important data is that the pressure made by the more developed nations (including the North's industries that pressured for the TRIPS) were able to set rules that, according to some experts, constitute an imminent danger for the development perspectives of the poor nations".

\subsection{Rights and duties}

Intellectual property is made of rights of patrimonial and personal nature, which confer the author the full ability and exclusive rights to exploit his or her work in every way and especially, the rights of exploitation, distribution, public dissemination and transformation, never without his or her authorization, except in those cases foreseen by the respective laws.

\subsection{Characteristics}

Intellectual property rights have the following characteristics:

- Exploitation rights are transmitted "mortis causa", by any of the means admitted by the law.

- It may be transmitted through "inter vivos" transfer. Intellectual property law legitimates the recognized owner of the rights, the ability to urge stopping the illicit activity from the offender and demand a compensation for the material and moral damages caused.

- Property rights related to works and other productions protected by the Intellectual Property Law can be an object of registration.

- The owner or exclusive assignee of an exploitation right on a work or production protected by law may put ahead of his or her name the symbol (C) specifying the place and year of its dissemination (Samuelson, et al 1994, p.137).

\subsection{Registration of intellectual property}

According to the Uruguay Round (1994), Intellectual Property Register has the aim of registration of rights corresponding to works, performances or original literary, artistic, scientific works expressed by any medium or support, tangible or intangible, currently known, or that might be invented in the future. They have the legitimacy to ask a registration: authors and all the original owners of intellectual property rights with respect to the work itself, performance or production, as well as the successive owners of the intellectual property rights.

\subsection{The North American Free Trade Agreement (NAFTA)}

The NAFTA, signed in 1992 by Mexico, Canada, and the United States, began in January 1st. 1994 and has recently been reviewed by the three signatory countries. It contains a comprehensive chapter on intellectual property, directly based on the TRIPS agreement. In general, the NAFTA foresees some higher protection standards compared to the TRIPS.

The NAFTA did not consider the principle of rights depletion from Article 6 of the TRIPS and there were not equivalent regulations to those of "Objectives" and "Principles" from that agreement (those who offer a framework for national legislation, including one about the control of abusive practices). The 
NAFTA brought to the authors' exclusive rights a higher power than the TRIPS (with the exception of moral rights that are not applied for the United States). It limits the mandatory licenses for reproduction and translation permitted by the Berne Convention. Foresees specific protection in regards to satellite signals that carry programs and a minimum lasting for brands (ten years) bigger than the TRIPS (seven years). (GATT, 1987a, p.8).

\subsection{The TRIPS and the WTO}

The TRIPS has tipped the scales in favor of the owners of intellectual rights of technology and knowledge, generating adverse effects on the consumer's wellbeing, technology transference, environment and economic development. According to Graz (1988), when the Uruguay Round on multilateral negotiations took place, several developing countries opposed to including intellectual property rights in the agenda. Nevertheless, under the United States threat of reprisals based on its Article 301 from its commerce law, they finally had to accept it and the TRIPS became part of the WTO agreements.

Twenty-two years after the founding of the WTO, there are social and economic problems caused by the TRIPS. There is a general perception that the WTO system favors the owners of intellectual property rights and the big corporations from the industrialized world performing against the public interest. This goes against Corporate Social Responsibility or CSR. According to Porter and Kramer (2006), a company committed with CSR must integrate a social perspective to its central operations in order to guide its business strategy. This is not the case under the TRIPS.

The owners of intellectual property rights, mostly the North's big companies, have so far obtained special monopoly rights avoiding competition and enjoying the benefits that a monopoly represents. The earnings produced are at the expense of the consumers, human needs assistance and from other producers, researchers, and scientists restrained, at many cases, by the banning of using patented materials. This affects sustainability, environment and economic development, which is against the concepts defended by the CSR.

Scholars in the field of CSR who consider it a corporate governance's social perspective (Tricker, 2012), express that corporations must acknowledge the interests of all those affected by the corporation's decisions, including consumers, employees, and managers, partners at the supply chain, bankers, stockholders, the local community, the interest of the society in general on environment and the state. Evidently, the TRIPS does not favor these interests.

In addition, from the Stakeholders' Theory, defined by Freeman (1984), as the balanced attention to the demands of all the stakeholders, it is evident that many of the North's companies are not fulfilling their social responsibilities. The Stakeholder Theory states that companies have duties or responsibilities towards all those affected by their performance. (Freeman and Reed, 1983; Freeman, 1984; Langtry, 1994; Donaldson and Preston; 1995; Wicks, 1996; Atkinson, Waterhouse and Wells, 1997; Phillips R., 1997; Clarkson, 1994; Marens and Wicks, 1999; Reed, 1999; Post, Preston and Sachs, 2002; Schneider, 2002; Foster and Jonker, 2003; Greenwood and Simmons, 2004; Polonsky and Scott, 2005; Laplume, Sonpar and Litz, 2008; Derry, 2012).

Before the TRIPS Agreement, each country was able to set its own policies on intellectual property rights. Nowadays, the price of some consumer goods are fixed by the companies that own the intellectual property right and it results to be much higher compared to the price at a free competitive market. Correa (1994), mentions that the TRIPS Agreement complicates the technological upgrade process. A research made by Jayashree Watal (2001), illustrates Correa's statement. 


\section{METHODOLOGY}

This research is supported by secondary sources of information. The current situation of the TRIPS Agreement in Mexico is analyzed through the consultation of previous studies from specialists on the topic, specialized magazines, books and documents from involved organizations such as WTO, (World Trade Organization) WIPO (World Intellectual Property Organization), IMPI (Mexican Institute for Industrial Property) and The Global Compact from the United Nations to mention some. This research describes how the aforementioned agreement puts in place the obligations, which are these, and if they benefit or not Mexico's technological advance. We described the TRIPS Agreement implementation and its influence on Mexico's technological upgrade, modernization and industrialization. These studies show the benefits and obstacles of the agreement as well as the kind of impact it had on Mexico and other nations.

This study is descriptive. Its objective is describing and characterizing a problem, its origin, evolution, and leaps, without getting to causal inferences or to variables association. Both assumptions proposed for this research imply a descriptive study. In order to analyze data, these are narrated once they were interpreted, just as these are described as the outcome of the documental analysis.

We made an information processing through the analysis of the documents collected from trustworthy sources (essays, specialized magazines, documents from specialized organizations) which made possible getting to a final judgment. This research shows an interpretation of the information described by the documents, which made possible to make inferences from the documental research, integrating diverse opinions from specialists. Then, a table was elaborated in order to analyze implied variables and the influence of some on others as well as the effects they have on the less developed nations.

Comparative tables describe technological advances, innovation, and international competitiveness. This research looks for showing the differences and disadvantages that the TRIPS Agreement represents on the less developed nations and the relation of these three factors between them. Comparisons were made between countries with different development degree, the role played by the different variables was analyzed, evident advantages and disadvantages were described and different specialized opinions are presented, which at the same time, mostly show similarities with the aim of the research. With the aforementioned, it was possible to get a wider view of the situation, which makes possible to propose the corresponding recommendations from different points of view.

\subsection{Definition of implied variables}

Assumption 1

- $\mathrm{VI}_{1}$ TRIPS Agreement. (Independent);

- $\mathrm{VD}_{1}$ Technological upgrade, modernization and industrialization (Dependent). Assumption 2

- $\mathrm{VI}_{2}$ Intellectual property titles. (Independent);

- $\mathrm{VD}_{2}$ Commerce and international competitiveness (Dependent).

\subsection{Conceptual definition:}

$\mathrm{VI}_{1}$ TRIPS Agreement: It is an agreement that sets minimum standards on patents, royalties, trademarks, brands, industrial designs, geographical indications, integrated circuits, and non-disseminated information (trade secrets). 
$\mathrm{VD}_{1}$ Technological upgrade, modernization, and industrialization: It is the value differentiation proposed in order to improve commercial capacities, the foundation for a competitive advantage at innovation precisely for exploiting advantages to face competition.

$\mathrm{VI}_{2}$ Intellectual property titles: It is a cluster of exclusive patrimonial rights given to physical or moral persons that carry out the creation of artistic works or that develop inventions or innovations and of those who adopt commercial indications, being these products, creations or commercial objects.

$\mathrm{VD}_{2}$ Commerce and international competitiveness: International commerce is an avenue marked by a growing importance for economic development. Therefore, business derived from this commercial accord, allow the big multinational companies to get excellent earnings. Medium and small companies in Latin America are discovering that the world market offers enormous opportunities.

The weight of a country or a region's competitiveness must take into account the context and according to the international environment from where the analyzed country is part. Talking about competitiveness requires considering the changing conditions in which the world performs. Competitiveness is the capacity of a private or public organization of systematically sustaining comparative advantages that may allow them reaching, keeping and improving a certain position in the socio-economic environment.

\section{Dimensions (indicators)}

$\mathrm{VI}_{1}$ TRIPS Agreement and $\mathrm{VI}_{2}$ Intellectual property titles:

D1 Royalties

D2 Patents

D3 Trademarks

$\mathrm{VD}_{1}$ Technological upgrade, modernization and industrialization:

D1 Financial stability

D2 Technological investment

D3 National economy

$\mathrm{VD}_{2}$ Commerce and international competitiveness:

D1 Imports

D2 Exports

\section{RESULTS AND DISCUSSION}

\subsection{Integration of the TRIPS Agreement}

Based on documental research, from the literature review, some reflections were made. These were validated by the research made by the scholars mentioned previously. Their findings were analyzed and discussed in the literature review section. Therefore, we found the following results and problems:

1. The companies owning intellectual property rights have increased the price of consumer products, including medicines, at the expense of consumers from both, industrialized and developing countries. This is evidently against social responsibility, which those companies are supposed to assume, according to the Global Compact Principles from the UN, as aforementioned.

2. Developing nations have to pay very high costs in order to make use of technology, or even worse, they are not able to get authorization from the owners of intellectual property rights, so the producers from the South face very serious obstacles to improve their technology.

3. "Bio piracy". Companies, mostly from the North, patent natural resources, and knowledge on its utilization mostly generated at the South. This implies an unjust appropriation of knowledge developed by farmers and indigenous groups, which also affects their right to make use of their own resources, affecting consumers. This is against CSR and the Stakeholders Theory (Freeman, 1984), that Derry (2012) calls "a form of capitalism based on 
values", where even those stakeholders that are real but marginalized, may claim their legitimate role.

4. The owners of intellectual property rights, mostly the big companies from the North, have obtained special monopoly rights in order to avoid competition from others and enjoy the enormous benefits at the expense of consumers, assistance to human needs, as well as to other producers.

5. Scholars and scientists, in many cases, are restrained by the prohibition of using patented materials.

6. Economic development and environment are also affected. This goes against Elkington's (1997), Triple Bottom Line of CSR: people, profit, and the planet.

The TRIPS implementation moves away from CSR and from the essence of the Stakeholders' Management Theory, which should reside in the firm's participation in the creation of moral and sustainable relations. (Freeman, 1994; Wicks, Gilbert and Freeman, 1994).

\subsection{Problem and main elements analysis: winners and losers}

The relation between intellectual property and international commerce shows different edges. It may favor certain countries increasing their foreign commerce, mainly, those that count on a bigger technological capacity but it becomes a barrier to commerce through the abuse of its implementation.

With a more homogeneous set of rules on intellectual property, companies are able to use commerce as the main medium to exploit their innovations without turning to direct investment or technology licenses. Therefore, the nations that receive more benefits from the modifications of the national and communal legislations to homogenous standards of intellectual property are those that own technological capacity creating value locally and expanding their exports to the rest of the world. Exercising intellectual property rights may generate barriers discriminating the access to products protected by those rights. Some subjects can be distinguished since they have a direct relation with commerce:

- Measures that impede the commerce of counterfeit goods or copyrights defrauding.

- Regulation of emerging anticompetitive practices on intellectual property rights, through a specific legislation or through the general laws of competition defense.

- Restrictive practices of license contracts.

- The focus on the regulation of assumptions considered at the aforementioned points is crucial in order to achieve a normative able to generate competitive markets in order to increase economy and the development of Latin American nations.

With all the described reasoning, some questions arise that will be answered in this research.

\subsection{Questions of the research}

Question 1: Does The TRIPS agreement influence the technological upgrade process, modernization, and industrialization in Mexico?

Question 2: Do the rights granted by intellectual property rights represent a barrier to Mexico's commerce, a restriction to its international competitiveness and social responsibility?

The aim of this research is describing the TRIPS agreement's effect on the process of Mexico's technological upgrade, modernization and industrialization and determining the focus that international standards implementation must follow in Mexico's regulations in order to achieve an equilibrium between intellectual property rights and its international competitiveness. Besides, this document looks for:

- Describing the current situation of the TRIPS agreement implementation in Mexico.

- Describing the TRIPS agreement and its effects on Mexico's:

- Technological upgrade 
- Modernization and

- Industrialization

- Explaining how it affects social responsibility development.

- Analyzing the effects that this principles' implementation has had on technological advance.

\subsection{Assumptions of the research: difficulties and restrictions}

- $\quad$ S1 The TRIPS agreement makes difficult Mexico's technological upgrade, modernization, industrialization and social responsibility development.

- $\quad$ S2 The rights granted by intellectual property rights are barriers to Mexico's commerce and restrict its international competitiveness.

\subsection{Competitiveness, technological development and innovation}

Table 1, next, shows which are the world's 15 most competitive countries and in which place they rank compared to Mexico.

The previous table shows that there is a wide gap between the most competitive countries and emergent nations, like Mexico.

Table 1

Competitiveness index

\begin{tabular}{|l|c|c|c|}
\hline \multicolumn{1}{|c|}{ Country } & $\begin{array}{c}\text { Place in } \\
\mathbf{2 0 1 6 - 2 0 1 7}\end{array}$ & $\begin{array}{c}\text { Score } \\
\mathbf{2 0 1 6 - 2 0 1 7}\end{array}$ & Place in 2015 \\
\hline Switzerland & 1 & 5.81 & 2 \\
\hline Singapore & 2 & 5.72 & 3 \\
\hline United States & 3 & 5.70 & 5 \\
\hline Netherlands & 4 & 5.57 & 4 \\
\hline Germany & 5 & 5.57 & 9 \\
\hline Sweden & 6 & 5.53 & 10 \\
\hline United Kingdom & 7 & 5.49 & 7 \\
\hline Japan & 8 & 5.48 & 11 \\
\hline Hong Kong & 9 & 5.48 & 15 \\
\hline Finland & 10 & 5.44 & 16 \\
\hline Norway & 11 & 5.44 & 13 \\
\hline Denmark & 12 & 5.35 & 13 \\
\hline New Zealand & 13 & 5.31 & $\mathbf{5 7}$ \\
\hline Taipei & 14 & 5.28 & 7.27 \\
\hline Canada & 15 & $\mathbf{4 . 4 1}$ & \\
\hline Mexico & $\mathbf{5 1}$ & & \\
\hline
\end{tabular}

Source: World Economic Forum, Technological Index 2016-2017

At the 2016 WEF's study on the technological index (technological readiness), Mexico ranks 73 out of 138 countries analyzed, with 4.0 points and ranked 51 in global competitiveness with 4.41 points (WEF, 2016-2017), (see table 2). The United States ranks 14 in the technological index with 6.0 points and third in global competitiveness with 5.7 points, this is, Mexico is behind more than two-thirds compared to the United States. Mexico is lead in the technological index by six nations from Latin America: Chile, ranked 39 with 5.1 points; Uruguay, ranked 356 with 5.2 points; Costa Rica, ranked 45 with at the technological index with 4.8 points; Panama, ranked 53 with 4.6 points; Colombia, ranked 64 with 4.4 points in the 
technological index and Brazil, ranked 59 with 4.4 points. It was also mentioned that Canada, Mexico's other partner at the NAFTA, is ranked 21 in the technological index with 5.8 points.

Technological innovation refers to the transformation of ideas into new and useful products and/or processes, as well as technological and meaningful improvement of those that already exist. In order to achieve technological development, the TRIPS Agreement's terms must be reconsidered. The prevalent situation reveals that Mexico, as the rest of the developing nations, is far away from the developed countries.

The WEF divides the 9th. Pillar of Competitiveness in two sections: Technology Adoption and Use of the ITC's. The first includes the availability of the most recent technologies, absorption of technology by the companies and technology transference. The second one includes Internet users, wideband internet subscriptions, subscriptions to wideband mobile telephony, subscriptions to mobile telephony, and combined telephone lines. Table 2, next, shows the countries better prepared for technological innovation or technological readiness. It shows the existing gap between Mexico, an emergent economy, with respect to the nations ranked the first ten in this subject.

Table 2

Technological index (technological readiness)

\begin{tabular}{|l|c|}
\hline \multicolumn{1}{|c|}{ COUNTRY } & SCORE \\
\hline 1.- Switzerland & 6.41 \\
\hline 2.- Luxembourg & 6.40 \\
\hline 3.- United Kingdom & 6.33 \\
\hline 4.- Sweden & 6.29 \\
\hline 5.- Hong Kong & 6.21 \\
\hline 6.- Netherlands & 6.18 \\
\hline 7.- Norway & 6.17 \\
\hline 8.- Island & 6.17 \\
\hline 9.- Singapore & 6.14 \\
\hline 10.- Germany & 6.11 \\
\hline 73.- Mexico & $\mathbf{3 . 9 7}$ \\
\hline
\end{tabular}

Source: World Economic Forum, Technological Index, 2016-2017.

The previous table shows the 10 most prepared countries for technological innovation. Most of them coincide with the most competitive nations. In conclusion, one factor relates to the other, since in order to be competitive, a country needs to innovate, what at the same time relates to its technological index.

Innovation is the 12th. Pillar of competitiveness, according to the Competitiveness Report 2016-2017 from the WEF (2016). It is particularly important for economies whenever they get closer to the frontiers of knowledge, the possibility of generating added value and when the action of integrating and adapting foreign technologies tends to disappear. It includes the following factors:

Innovation capacity; quality of the institutions in scientific research; investment of companies in research and development; collaboration between companies and universities in research and development; high technology products acquisition by governments; availability of scientists and engineers; application for patents registration and intellectual property rights, WEF (2016).

The document mentions that in the economies - above all emergent ones- companies must design and develop innovative products and processes in order to maintain competitiveness and move towards activities capable of generating more added value. This requires an environment that eases innovation and having the support from the private and the public sectors. Enough investment in research and development, especially from the private sector. Likewise, there is a lack of institutions that carry out highquality scientific research and that may generate the basic knowledge in order to develop the new 
technologies and extensive collaboration with the universities and industry with respect to investigation and technological development. Moreover, very important, intellectual property protection.

\subsection{Limitation for technology transference}

The TRIPS Agreement has also adverse effects on development. Historically, technology transference has played a key role in industrialization and a great amount of that transference took place when companies imitated and adopted technologies used by others, through reverse engineering. The developing world producers face big difficulties in order to follow that path and sometimes-unbeatable obstacles.

"National companies wanting to make use of a technology, must get a permission from the owner of the patent - who may give it to them or not, beyond if who is asking for it is willing to pay its commercial or market price- and pay, besides, very costly royalties. Many companies are not able to pay those prices and those who could do it, often get to the conclusion that the cost reduces their competitiveness. The TRIPS Agreement's regime is a serious impediment for developing countries that try to improve their technology, modernize and get industrialized." (Smith, 1995, p.16)

Carlos Correa (1994), an expert in intellectual property rights, has pointed out that the TRIPS Agreement restricts reverse engineering and other innovation methods used by industrialized countries during their industrialization process period, complicating technological update. Even though some agreements have clauses on financial aid and technology transference, in the practice, the countries from the South see that those from the North do not fulfill their obligations.

\subsection{The influence of the TRIPS on Mexico's technology updating, modernization, commerce and international competitiveness}

Next, tables 3a, 3b and 3c show how the TRIPS Agreement affects technological updating, modernization and industrialization of developing countries, in this case, Mexico. Similarly, the influence on its commerce and international competitiveness. 
Table $3 \mathrm{a}$

Effects of the TRIPS Agreement and intellectual property titles (IPT) on technological updating, modernization, and industrialization and its influence on developing countries' commerce and competitiveness (Mexico)

\begin{tabular}{|c|c|c|c|c|}
\hline \multirow{2}{*}{$\frac{\text { Variable affected }}{\left(\mathrm{VI}_{1} \text { and } \mathrm{VI}_{2}\right)}$} & \multicolumn{2}{|c|}{ Effects of the variables } & \multicolumn{2}{|c|}{ Variable affected } \\
\hline & Developing countries (Mexico) & Developed countries & $\mathrm{VD}_{1}$ & $\mathbf{V D}_{2}$ \\
\hline $\begin{array}{l}\text { TRIPS } \\
\text { Agreement }\end{array}$ & $\begin{array}{l}\text { Established norms may severely damage the } \\
\text { poor nations' development and social } \\
\text { perspectives. }\end{array}$ & & $\mathbf{X}$ & $\mathbf{X}$ \\
\hline $\begin{array}{l}\text { Intellectual } \\
\text { property titles }\end{array}$ & & $\begin{array}{l}\text { General perception that } \\
\text { the W'TO's system } \\
\text { decidedly favors the } \\
\text { owners of intellectual } \\
\text { property rights and the big } \\
\text { companies from the } \\
\text { industrialized world. }\end{array}$ & $\mathbf{X}$ & \\
\hline $\begin{array}{l}\text { Intellectual } \\
\text { property titles }\end{array}$ & & $\begin{array}{l}\text { The companies that own } \\
\text { intellectual property rights } \\
\text { have increased the prices } \\
\text { of consumer goods }\end{array}$ & & $\mathbf{X}$ \\
\hline $\begin{array}{l}\text { Intellectual } \\
\text { property titles }\end{array}$ & $\begin{array}{l}\text { Developing countries must pay very high } \\
\text { prices in order to make use of technology } \\
\text { or they do not get authorization from the } \\
\text { owners of intellectual property rights, } \\
\text { consequently, they face serious obstacles } \\
\text { for improving their technology. }\end{array}$ & & $\mathbf{X}$ & \\
\hline
\end{tabular}

Source: own elaboration. Data from "Decisión empresarial”, IMPI and OMPI.

Table $3 b$

Effects of the TRIPS Agreement and IPT on technological updating, modernization, and industrialization and its influence on commerce and international competitiveness at developing countries (Mexico)

\begin{tabular}{|c|c|c|c|c|}
\hline Variable affected & Effects of & he variables & & \\
\hline$\left(\mathrm{VI}_{1}\right.$ and $\left.\mathrm{VI}_{2}\right)$ & Developing countries (Mexico) & Developed countries & $\mathbf{V D}_{1}$ & $\mathbf{V D}_{2}$ \\
\hline $\begin{array}{l}\text { Intellectual } \\
\text { property titles }\end{array}$ & & $\begin{array}{l}\text { Owners of intellectual property } \\
\text { rights, mostly the big companies } \\
\text { from the North, have obtained } \\
\text { special monopoly rights in order } \\
\text { to avoid competition from others } \\
\text { and enjoying the enormous } \\
\text { benefits that a monopoly implies. }\end{array}$ & & $\mathbf{X}$ \\
\hline $\begin{array}{l}\text { TRIPS } \\
\text { Agreement }\end{array}$ & $\begin{array}{l}\text { Researchers and scientists are } \\
\text { constrained by the prohibition to } \\
\text { make use of patented products. } \\
\text { Economic, social development and } \\
\text { environment are also affected. }\end{array}$ & & $\mathbf{X}$ & $\mathbf{X}$ \\
\hline $\begin{array}{l}\text { Intellectual } \\
\text { property titles }\end{array}$ & $\begin{array}{l}\text { The prices of several products } \\
\text { protected by intellectual property } \\
\text { rights are inflated, in certain cases, } \\
\text { way above production costs. }\end{array}$ & & & $\mathbf{X}$ \\
\hline $\begin{array}{l}\text { Intellectual } \\
\text { property titles }\end{array}$ & $\begin{array}{l}\text { Many companies are not able to pay } \\
\text { those prices; and those that could } \\
\text { do it, usually conclude that the cost } \\
\text { reduces their competitiveness. }\end{array}$ & $\begin{array}{l}\text { National companies willing to } \\
\text { make use of a technology must } \\
\text { get the owner's permission and } \\
\text { pay very costly royalties. }\end{array}$ & $\mathbf{X}$ & $\mathbf{X}$ \\
\hline
\end{tabular}

Source: own elaboration. Data from “Decisión empresarial”, IMPI and OMPI. 
Table 3c

Effects of the TRIPS Agreement and IPT on technological updating, modernization, and industrialization and its influence on commerce and international competitiveness at developing countries (Mexico)

\begin{tabular}{|c|c|c|c|c|}
\hline Variable affected & \multicolumn{2}{|c|}{ Effects of the variables } & \multicolumn{2}{|c|}{ Variable affected } \\
\hline$\left(\mathrm{VI}_{1}\right.$ and $\left.\mathrm{VI}_{2}\right)$ & Developing countries (Mexico) & Developed countries & $\mathrm{VD}_{1}$ & $\mathbf{V D}_{2}$ \\
\hline $\begin{array}{l}\text { TRIPS } \\
\text { Agreement }\end{array}$ & $\begin{array}{l}\text { The TRIPS Agreements' regime is a } \\
\text { serious impediment for developing } \\
\text { countries resolved to improve their } \\
\text { technology and achieving their } \\
\text { modernization and industrialization. }\end{array}$ & & $\mathbf{X}$ & \\
\hline $\begin{array}{l}\text { TRIPS } \\
\text { Agreement }\end{array}$ & $\begin{array}{l}\text { Poor countries are required to abide by } \\
\text { the norms on intellectual rights, what } \\
\text { impedes them to adopt the same } \\
\text { technological path as the North. }\end{array}$ & & $\mathbf{X}$ & \\
\hline $\begin{array}{l}\text { TRIPS } \\
\text { Agreement }\end{array}$ & $\begin{array}{l}\text { The TRIPS Agreement restricts reverse } \\
\text { engineering and other methods of } \\
\text { innovation through imitation used by } \\
\text { industrialized countries during their } \\
\text { industrialization period, besides } \\
\text { complicating, more than ever, their } \\
\text { technological updating process. }\end{array}$ & & $\mathbf{X}$ & \\
\hline $\begin{array}{l}\text { TRIPS } \\
\text { Agreement }\end{array}$ & $\begin{array}{l}\text { Some environmental agreements contain } \\
\text { clauses on financial aid and technology } \\
\text { transference but in the practice, nations } \\
\text { from the South see that those from the } \\
\text { North do not fulfill their duties. }\end{array}$ & & $\mathbf{X}$ & \\
\hline
\end{tabular}

Source: own elaboration. Data from “Decisión empresarial”, IMPI and OMPI.

From the previous tables, it is possible to deduce that the negative influence of independent variables (VI 1 TRIPS Agreement and V $I_{2}$ Intellectual Property Titles), is more meaningful at developing countries, and at the same time is favoring developed nations.

\section{DISCUSSION}

A matter of business and social responsibility. Historically, intellectual property is a right whose evolution links to technology development and a fiscal right of political and economic structures of the society where it takes place. It is necessary to develop research that permits demonstrating that there is not an adequate protection to intellectual property in Mexico; therefore, Mexican companies will not assign it the right value it intrinsically has. Human rights defense will be unable to protect them from the system, and at the same time depriving, paradoxically, the owners of intellectual property from one of the most sensitive human rights: the right to own the results of work and talent. This, besides, would violate two of the principles from the United Nations Global Compact: Principle 1, Human Rights: "Businesses should support and respect the protection of internationally proclaimed human rights within their influence environment" and Principle 2: "Make sure that they are not complicit in human rights abuses". (Global Compact, UN, 1999). The violation of these two principles certainly affects negatively the social development and social responsibility in Mexico.

Particularly, it is of vital importance doing research on intellectual property and its implementation in Mexico and the effect it has on international competitiveness. This will make possible having a wider vision of what surrounds Mexico's international commerce and the factors that are part of its development. 
Corrective measures. It is time to get rid of those imbalances and asymmetries. The TRIPS Agreement should be deeply examined and incorporate several modifications. Then, extend the transition term given to the developed countries in order to implement the clauses of the Agreement. It is necessary to give the nations from the South the opportunity to choose from diverse options and make them clear about the advantages and disadvantages of each one.

Developing countries should not suffer from bilateral pressures through regional agreements or in the access process to the WTO. The clauses on technology transference and the TRIPS objectives should be mandatory by law, so the industrial countries and their companies would really make effective the technological transference to the developing nations.

Probably, as Vogel (2008) states, CSR might be effective only through a wider involvement from the NGO's or as Frederick (2005) says, maybe there is the need to elaborate more laws or also, as Reich (2007) proposes, perhaps there is a need for a strengthening of governmental regulations, in this case from the nations affected by the TRIPS.

Last, WTO's members should reconsider if the TRIPS Agreement should be part of the organization. Intellectual property rights are not a commerce business, but a way of protectionism, which constricts international technology transference and institutionalizes the privileges of monopolies with the consequence of competition reduction.

Consequences of the TRIPS Agreement and intellectual property rights. Intellectual property rights are not "natural rights", but statutory privileges in order to reward inventions and bring incentives. A rights system must ease that this privileges' conferring corresponds to the public interest, including the consumer's welfare, the right of other producers to make use of technology and the right to development and environmental protection. The TRIPS is not favoring social responsibility and is violating the Principles of the Global Compact from the UN, such as Number 2: organizations must make sure that they are not complicit in human rights abuses; is also violating all the principles referring to environment. In first place, Principle number 7: businesses should support a precautionary approach to environmental challenges also, Principle Number 8: undertake initiatives to promote greater environmental responsibility and Principle Number 9: to encourage the development and diffusion of environmentally friendly technologies (Global Compact, UN, 1999).

"The TRIPS Agreement has provoked a significant transfer: from public interest to the monopoly privileges of the owners of intellectual property rights. In that agreement are framed the legal clauses that must be followed, because on the contrary, might be punished with commercial penalties, a system where "one size fits all" for the countries members of the WTO, regardless their development degree. Even though the consequences of the inadequate clauses that affect above all, the developing nations, the consumers from the North also suffer, as well as the general public and the scientific community in particular". (Samuelson, P.et al, 1994, p.87).

Consumers begin realizing that prices of some products protected by intellectual property rights are very high, and in some cases very far away from production costs because companies that own a patent or the right to manufacture a product, might impede competition.

The TRIPS Agreement brings very bad consequences for developing nations. If the North's countries had adhered the minimum of exigencies of the Agreement on development, similar to what the nations from the South nations have to, they would have been incapable to achieving their current technology levels. This Agreement favors protectionism above commercial liberalization and its purpose is impeding the developing countries to become effective competitors. This has created a bad reputation to the Agreement and shows that for most of the owners of patents from transnational companies as well as for the wealthiest countries' governments, the right to monopoly and its enormous benefits, are above the sick's people's right to health and life. When public opinion at South Africa and other developing nations expressed their indignation, they found support in several press reports and NGO's from the North, such as Médecins Sans Frontières, MSF Oxfam, RAFI (Rural Advancement Foundation International) and 
GRAIN, Genetic Resources Action International. Even one of the pharmaceutical companies announced that it would bring the South a combination of two medications against AIDS at 600 dollars, declaring that at that price it would not get profits ${ }^{3}$.

Abuses have been constant and some have captured the world's attention. Daraprim, was acquired by Turing Pharmaceuticals laboratories in 2015.The CEO and main owner is the American businessperson Martin Shkreli. He acquired the medicament's patent rights used for the treatment of illnesses such as toxoplasmosis, AIDS, and cancer and raised the price to the public from overnight, from USD 13.50 to USD 750 a tablet (The New York Times, 2015). This means an increase of 555 percent, leaving it out of reach of the health sector and patients at the United States and the rest of the countries, even more at the less developed nations. On informatics programs, prices usually are well above production cost. The majority of consumers from the developing world could not buy them at the market price, what cancels their access to an important part of the "knowledge society".

\section{CONCLUSION}

Consequences of the TRIPS Agreement. Disenchantment with respect to the TRIPS Agreement due to certain points not considered and to some benefits promised and that never became true.

The TRIPS Agreement contains several references and clauses on technology transference, among them, Article 7, on the promotion of innovation and technology transference and 66.2, on the obligation from industrialized countries to offer incentives to their companies that promote technology transference to the less developed nations. Nevertheless, the North has almost done nothing. Therefore, trust about sincerity and intentions from industrialized countries has been eroded, same as the image and trust on the intellectual property rights system.

The TRIPS Agreement's system has favored the owners of intellectual property rights leaving the users of technology defenseless. Privileges and rights from the first ones have been overprotected and they have not fulfilled their duties towards society and public wellness avoiding their social responsibility. According to Vogel (2008), CSR is the future of business, is what they need to survive and prosper in a world where business behavior is under the loupe. Therefore, a critical dimension for CSR is improving the citizen's standard of living in developing countries, where international firms carry out their business.

There are asymmetries between the North and the South about costs and benefits. Implementing strict world norms on intellectual property rights will give place to an enormous increase of benefits for industrialized countries and those who will pay for those earnings will be the developing nations.

What should be done? Analyzing Article 27.3 (b) from the TRIPS Agreement should be useful for canceling the artificial distinctions between certain organisms and procedures that might be excluded from the patents system and others that may not. This clarification can be done through an amendment to the aforementioned article, with the aim of operating certain modifications at national legislation in accordance with the new mandate. In addition, every country should have the right to exempt from the patent's regime, technologies which are innocuous to the environment.

Clauses on technology transference and the TRIPS' objectives should be mandatory by law, so industrialized countries and their companies should make effective technology transference and its dissemination at developing countries.

Last, WTO members should consider again if the TRIPS Agreement must be part of the organization. Intellectual property rights are not a commercial subject but they constitute instead, a form

\footnotetext{
3 “This fact was equivalent to admitting publicly that the profits margin for a 10,000 dollars medicament sales - and even more at the USA- is astronomic. The offering of reducing the price for developing nations is understood by some as an attempt to calm down public indignation, save the patents system of any danger and counteract the need from the South to exercise its liberty of choice about patents" (Chasen Ross, J, and Wasserman, J., 1993, p.45)
} 
of protectionism that restricts international transference of technology, institutionalizes monopolies' privileges and reduces competition.

Educating in CSR, a possible solution. Besides the lobbying and pressure from the developing countries at the different world forums like the WTO in order to modify the prevalent conditions of the TRIPS, education in CSR at the universities from both, developing and developed countries, can be of possible help for the future. Education is a key driver of students' moral and ethical development and the students of today will become the top managers and policymakers of the future (Armstrong et al (2003). Possibly, they could change in the future the current conditions under a more socially responsible perspective.

It is becoming increasingly necessary to give greater importance to ethical values and CSR policies in higher education institutions (Gaa and Thorne, 2004; Bampton and Maclagan, 2005; Block and Cwik, 2007). Business schools and faculties of economics and business administration have a stake and responsibility to produce graduates who act in an ethical and responsible way and instigate socially and ethically acceptable operations when they join a company (Pfeffer and Fong, 2004; Cornelius, Wallace, and Tassabehji, (2007); Waples et al., 2008).

In today's globalized world as corporation's gain power and economic relations grow, the need for increased commitments and responsibilities arises. This gives way to the need to not only carry out more research on CSR from a stakeholder perspective and develop programs that create understanding and awareness for all parties but also incorporate CSR curriculum into higher education institution programs.

Previous studies have noted the need to understand what type of business ethics and CSR curriculum have to be taught in business schools and how it has to be conducted to provide students with a solid background to respond to societal concerns (e.g. Gaa and Thorne, 2004; Bampton and Maclagan, 2005; Block and Cwik, 2007).

A research carried out in two universities, one in Canada, a developed country, and one in Mexico, an emerging economy, on similarities and differences in teaching CSR (González-Gómez, Erogul and Barragan, 2016), found that in both universities, a CSR course is mandatory for management students. It has the purpose to create awareness and to provide them with the foundations on theories of CSR and tools to engage in creating a sustainable economy, where both business and society benefit. Both universities include the core topics of CSR. They also consider the importance of stakeholders as strategic partners for the organization, and an ethical responsibility for organizations as described in the stakeholder management theory (Freeman et al., 2010). Maybe the hope to improve the unfair conditions of the TRIPS Agreement is precisely in the new generations of managers and economists if they receive an education on CSR.

For the moment, the claims list includes more time, flexibility and freedom. In that way, the developing countries may have other options for implementing the Agreement. That the industrialized countries and its companies do not take reprisals against the countries from the South. Analyzing the Agreement in depth, with the aim of eliminating problematic aspects and make effective the positive facets, such as the clauses on technology transference. To consider bringing completely the TRIPS Agreement out from the WTO. According to Freeman et al (2010), it is not possible to separate business from ethics and vice versa.

\section{REFERENCES}

Alcorta, L. \& Peres, W. (1995). Innovation systems and technological specialization in Latin American and Caribbean Exports: Maastricht. UNU.

Armstrong, M.B., Ketz, J. E. \& Owsen, D. (2003). Ethics education in accounting: moving toward ethical motivation and ethical behavior. Journal of Accounting Education, 49(2), 1-16.

Arrabal, P. (1991). Manual práctico de propiedad intelectual e industrial. Barcelona: Ediciones Gestión 2000, 
Atkinson, A. A., Waterhouse, J. H., \& Wells, R.B. (1997). A stakeholder approach to strategic performance measurement. Sloan Management Review, 38(3), 25-37.

Bampton, R., \& Maclagan, P. (2005). Why teach ethics to accounting students? A response to the skeptics. Business Ethics: A European Review, 14(3), 290-300. http://dx.doi.org/10.1111/j.1467-8608.2005.00410.x

Bayard, T., \& Elliott, K. (1994). Reciprocity and Retaliation in U.S. Trade Policy. Washington D.C Institute for International Economics.

Bergel, S. D., \& Battioli, E. (1993). En torno del abuso de derechos de propiedad intelectual y la competencia. Revista del Derecho Industrial, 43(15), 97-111.

Block, W., \& Cwik, P.F. (2007) Teaching business ethics: A classificationist approach, Business Ethics: A European Review, 16(2), 98-106. http://dx.doi.org/10.1111/j.1467-8608.2007.00480.x

Bondía, F. (1998). Propiedad Intelectual, su significado en la sociedad de la información. Barcelona, Ediciones Trivium.

Chasen R. J. \& Wasserman, J. (1993). Trade-related aspects of intellectual property rights, Kluwer Law and Taxation. Deventer, Netherlands. Boston: Kluwer Law and Taxation.

Clarkson, M., (1994). A Stakeholder Framework for Analyzing and Evaluating Corporate Social Performance. Academy of Management Review, 20, 92-117.

Commission of the European Communities. (1987). Trade-related aspects of intellectual property rights in the Uruguay Round: approach and priorities of the European Community, III/D/236/87- Brussels, EN (rev.2).

Cornelius, N., Wallace, J. \& Tassabehji, R. (2007). An analysis of corporate social responsibility, corporate identity and ethics teaching in business schools. Journal of Business Ethics, 76(1), 117-135. http://dx.doi.org/10.1007/s10551-006-9271-6

Cornish, W. (1989), Intellectual property: patents, copyright, trademarks and allied rights. London: Sweet \& Maxwell.

Correa, C. (1993). Legal protection and innovation in the software industry. World Competition, 17(1).

Correa, C. (1994). TRIPs Agreement: copyright and related rights. IIC, 4.

Derry, R. (2012). Reclaiming Marginalized Stakeholders. Journal of Business Ethics, 111(2), 253-264.

Donaldson, T., \& Preston, L. E. (1995). The Stakeholder Theory of the Corporation: Concepts, Evidence, and Implications. Academic Management Review, January 1, 20(1), 65-91.

Elkington, J. (1997). Cannibals with Forks: The Triple Bottom Line of 21st. Century Business. Capstone.

Foster, D., \& Jonker, J. (2003). Third generation quality management: the role of stakeholders in integrating the business into society. Management Auditing Journal, (4), 323-328.

Frederick, B. (2005). Vogel and Frederick, Together At Last! ... Well, Almost, A Review of David Vogel, The Market For Virtue: The Potential and Limits of Corporate Social Responsibility. Brookings Institution Press.

Freeman, E., \& Ginena, K. (2015). Rethinking the purpose of the corporation: Challenges from stakeholder theory, Article in Notizie di Politeia January

Freeman, E. R. (1994). The Politics of Stakeholder Theory: Some Future Directions. Business Ethics Quarterly, 4(4), 409-422.

Freeman, E. R., Harrison, J. S., \& Wicks, A. C. (2010). Stakeholder Theory, the State of the Art. Cambridge University Press. Cambridge.

Freeman Edward R. (1984). Strategic Management: A stakeholder approach. Pitman Publishing, Business, and Public Policy Series. Cambridge University Press.

Freeman, R., \& Reed, D. (1983). Stockholders and Stakeholders: a new perspective on corporate governance. California Management Review, 25, 88-106.

Fugate, W. (1990). Foreign Commerce and the antitrust law, vol. II, Fourth Edition. Washington D.C.: Little, Brown, and Co.

Gaa, J. C., \& Thorne, L. (2004). An introduction to the special issue on professionalism and ethics in accounting education. Issues in Accounting Education, 19(1), 1-6.

Gadbow, M., \& Richards, T. (1988). Intellectual Property Rights. Global Consensus, Global Conflict? Colorado: Westview Press. 
GATT. (1987a). MTN.GNG.NG11/W/2, Statement of the United States at the meeting of 25 March 1987, April 3.

GATT. (1987b). MTN.GNG/NG11/W/7, Submissions from participants on trade problems encountered in connection with intellectual property rights, May 29.

GATT. (1987c). Compilación de comunicaciones escritas y declaraciones orales (Preparada por la Secretaría), MTN.GNG/NG11/W/12, August 11.

GATT. (1987d). MTN.GNG/NG11/W/17, Suggestions by Japan for achieving the negotiating objective, November 23.

Global Competitiveness Index. (2017). GCI. Retrieved August 21, 2017 from http://reports.weforum.org/globalcompetitiveness-report-2014-2015/rankings/ web page.

González-Gómez, S., Erogul, M. S., \& Barragan, S. (2016) Similarities and differences in teaching corporate social responsibility: evidence from Mexico and Canada. Journal on Efficiency and Responsibility in Education and Science, 9(3), 70-80, doi: 10.7160/eriesj.2016.090303.

Graz, D. (1988). Propriété intellectuelle et libre circulation des marchandises. Suize: Université de Lausanne - Département de droit comparé.

Greenwood, M. R., \& Simmons, J. A. (2004). A stakeholder approach to ethical human resource management. Business and Professional Ethics Journal, 23(3), 3-23.

INTAL/BID. (1987). Régimen jurídico de la propiedad industrial en los países de la ALADI, Buenos Aires.

Jalife, M. (1994). Propiedad intelectual, Reseña El Economista. Editorial Sista, 1(30).

Khor, M. (2001). TRIPS Agreement and the WTO's Crisis of Legitimacy. Stanford Journal of International Relations, March 30.

Langtry, B. (1994). Stakeholders and the moral responsibilities of Business. Business Ethics Quarterly, 4(4), 431-443

Laplume, A. O., Sonpar, K., \& Litz, R. A. (2008). Stakeholder theory: Reviewing a theory that moves us. Journal of Management, 34(6), 1152-1189.

Levine, A., \& Matheson, J. (1995/1996). The NII White Paper and US copyright reform. Managing Intellectual Property, December 1995/January 1996

Lipszyc, D. (1993). Derechos de autory derechos conexos. Buenos Aires: Ediciones UNESCO, CREALC

Marens, R., \& Wicks, A.C. (1999). Getting real: stakeholder theory, managerial practice and the general irrelevance of fiduciary duties owed to shareholders. Business Ethics Quarterly, 2(2), 273-293.

OEA. (1973). Tratados y convenciones multilaterales sobre propiedad industrial en América. Washington D.C.

OTA. (n.d.). (Office of Technology Assessment), Multinationals and the U.S technology.

Pérez Miranda, R. (1994). Propiedad industrial y competencia en México. México D.F.: Ed. Porrúa.

Pfeffer, J. \& Fong, C.T. (2004). The business school "business": some lessons from the US experience. Journal of Management Studies, 41(8), 1501-1520. http://dx.doi.org/10.1111/j.1467-6486.2004.00484.x

Phillips, R. (1997). Stakeholder Theory and a principle of fairness. Business Etbics Quarterly, 7(1), 51-66.

Polonsky, M. J., \& Scott, D. (2005). An empirical examination of the stakeholder strategy matrix. European Journal of Marketing, 39(9/10), 1199-1215.

Porter, M., \& Kramer, M. (2006). Strategy and Society: The Link between Competitive Advantage and Corporate Social Responsibility, Harvard Business Review. (December) 21-38. Harvard. Post J., Preston L. \& Sachs S. (2002). Redefining the Corporation: Stakeholder Management and Organizational Wealth. Stanford University Press.

Pulido, M. (2006). Tecnología en México. Decisión Empresarial, 9(1).

Reed, D. (1999). Stakeholder management theory: a critical theory perspective. Business Ethics Quarterly, 9(3), 453-483.

Reich Robert, B. (2007). Super capitalism: The Transformation of Business, Democracy and Everyday Life. Alfred A. Knopf. Vintage Book.

Roffe, P. (1985). Transfer of technology: Unctad's draft international code of conduct. International Lanyer, 19(2). 
Samuelson, P., Davis, R., Kapor, M., \& Reichman, J. (1994). A Manifesto concerning the legal protection of computer programs. Columbia Law Review, 94(8).

Schneider, M. (2002). A Stakeholder Model of Organizational Leadership. Organization Science, 13(2), 209-220.

SELA. (1995). Más allá de la Cumbre de las Américas. Situación y perspectivas del Libre Comercio en el Hemisferio Occidental. San Salvador, julio de 1995.

Smith. P. (1995). International patent protection and United States exports: evidence in data. Lecture at "The international relations of intellectual property: challenges at the turn of the Century, 1, 1-5. Washington D.C.

The New York Times (2017). Drug Goes From \$13.50 a Tablet to \$750, overnight. web page consulted August 22, 2017.

Tricker, R.I. (2012). The Cultural Dependence of Corporate Governance. Keeping Good Companies, 64(1), 27-31.

U.S. International Trade Commission (USITC). (1988). Foreign protection of intellectual property rights and the effect on U.S. Industry and Trade (Report to the U.S. Trade Representative. Investigation No 332-245 under section 332 (g) of the Tariff Act of 1930). USITC Publ.2065, Washington UNESCO (1993), World Science Report 1993, París.

United Nations Global Compact. (1999). The Ten Principles of the UN Global Compact, web page. Consulted on August 31, 2017. https://www.unglobalcompact.org/what-is-gc/mission/principles.

Uruguay Round Agreements Act/Title V, Intellectual Property, United States Congress. (1994). web page, https://en.wikisource.org/wiki/Uruguay Round Agreements Act/Title V

Vogel David 1. (2006). The Market for Virtue, the potential, and limits of corporate social responsibility. Brookings Institution Press.

Waples, E. P., Antes, A. L., Murphy, S. T., Connelly, S. \& Mumford, M. D. (2008) A meta-analytic investigation of business ethics instruction. Journal of Business Ethics, 87(1), 133-151. http://dx.doi.org/10.1007/s10551-008$\underline{9875-0}$

Watal, J. (2001). Intellectual property rights in the WTO and developing countries. United Kingdom: Oxford University Press.

Wicks, A. (1996). Overcoming the separation thesis: The need for reconsideration of SIM research. Business and Society, 35(1), 89-118.

Wicks, A.C., Gilbert, D.R., \& Freeman, R.E. (1994). A feminist reinterpretation of the stakeholder concept. Business Ethics Quarterly, 4, 475-497.

World Economic Forum, WEF, The Global Competitiveness Report 2016-2017, web page, http://reports.weforum.org/global-competitiveness-index/, consulted on September 12, 2017.

Yusuf, A., \& Moncayo von Hase, A. (1992). Intellectual property and international trade. Exhaustion of rights revisited. World Competition, 16(1). 